Dariusz Makiłła

Wyższa Szkoła Finansów i Zarządzania w Warszawie e-mail: prawo@vizja.pl

telefon: +48225365435

DOI: $10.15290 / \mathrm{mhi} .2015 .14 .02 .02$

\title{
Próba reformy sądownictwa powszechnego z czasów bezkrólewia po ucieczce króla Henryka Walezego (1574)
}

\author{
SUMMARY \\ The Attempt to Reform a Common Judiciary during the Second Interregnum \\ Following the Departure of King Henry of Valois (1574)
}

The main purpose of the paper is to present the attempt to reform a common judiciary during the second interregnum following the departure from Poland of King Henry of Valois in 1574. The paper focuses on the problem of the current functioning of the judiciary during the interregnum which brought with it different practical questions and a general idea of the Polish gentry to reconstruct the system of common judiciary in the Commonwealth. The essence of this idea was the exclusive taking over of the judiciary by the gentry. It meant eliminating from the courts the local dignitaries comprising the common judiciary of the clergy and burghers. The program also provided to establish an appeal instance for all of the common courts. The project for the reform of the judiciary was presented during the convocation in 1574 and sent for acceptance to the local assemblies. However, the assemblies didn't agree with the idea to establish a common appeal instance for the country but according to the constitutional law of the Henrician Articles (1573) and decision of the convocation made in the General Confederation Act these decided to establish the appeal instances in every district. It moved a decision for establishing the common appeal instance to the beginning of the reign of King Stefan Batory (1578).

Key words: Interregnum of 1574-1575, the judiciary, the convocation in 1574, reform of the judiciary

Słowa kluczowe: bezkrólewie 1574-1575, sądownictwo, konwokacja 1574, reforma sądownictwa 
Kryzys państwa, który nastąpił w związku z wyjazdem króla Henryka z Polski 18 czerwca 1574 r., ledwie cztery miesiące po objęciu przez niego rządów ${ }^{1}$, miał przede wszystkim wymiar polityczny. Sytuacja okazywała się skomplikowana ze względu na stan ustrojowo-prawny, w jakim znalazło się państwo. Król bowiem wprawdzie żył - o czym wiedziano - ale opuścił, a w zasadzie - jak często określano - porzucił państwo, powodując konieczność określenia zasad, na jakich miałyby funkcjonować instytucje Rzeczypospolitej. Podstawowym problemem tego okresu stawało się więc polityczne rozstrzygnięcie, czy wskutek wyjazdu królewskiego, co uznawano często za ucieczkę², nastąpiło trwałe opróżnienie tronu $\mathrm{z}$ powodu - jak to precyzować zaczęto - śmierci cywilnej władcy ${ }^{3}$, co otwierałoby drogę do uruchomienia procesu wyboru nowego władcy, czy też stan ten należało traktować jako nieuzgodnione z Rzecząpospolitą, czyli reprezentującymi ją senatorami, ale przejściowe opuszczenie państwa, a tym samym powinno się nadal uznawać władzę nieobecnego króla? ${ }^{4}$ Problem ten rozstrzygnięto, uznając konieczność powołania organów władzy państwowej, które wskutek braku jasnych dyspozycji królewskich co do sprawowania rządów w państwie pod jego nieobecność, zdolne byłyby je sprawować. Pomimo jednocześnie nieogłoszenia formalnego zakończenia rządów królewskich, jako surogatu naturalnego zejścia króla, co formalnie nastąpiło na zjeździe stężyckim (12 maja - 4 czerwca 1575) $)^{5}$, instytucje jednak właściwe dla okresu bezkrólewia, jak zjazd konwokacyjny ${ }^{6}$, sejmiki przedkonwokacyjne ${ }^{7}$, czy pokonwokacyjne ${ }^{8}, \mathrm{w}$ praktyce jednak już powołano. W drodze kompromisu między różnymi stanowiskami, jakie zarysowały się odnośnie powstałej sytuacji zarówno po stronie szlachty, jak też senatorów, na zwołanej na 23 sierpnia 1574 r. konwokacji, podano królowi termin powrotu do Rzeczypospolitej, który ustalono na 12 maja 1575 r. Data ta miała

1 Ś. Orzelski, Bezkrólewia ksiąg ośmioro, czyli dzieje Polski od zgonu Zygmunta Augusta r. 1572 aż do r. 1576 skreślone przez Świętosława z Borzejewic Orzelskiego, starostę radziejowskiego. Przełożyt z rękopisu Cesarskiej Publicznej Biblioteki, przypisami i życiorysem uzupetnit Włodzimierz Spasowicz, Petersburg 1856, t. 2, ks. 4, s. 2-6; idem, Interregni Poloniae libri VIII, wyd. E. Kuntze, Kraków 1917, s. 237-241; W. Zakrzewski, Po ucieczce Henryka. Dzieje bezkrólewia 1574-1575, Kraków 1878, s. 55-66; M. Serwański, Henryk Walezy w Polsce, Kraków 1976, s. 180-201.

2 R. Heidenstein, Dzieje Polski od śmierci Zygmunta Augusta do roku 1594. Ksiag XII. Z łacińskiego przetłumaczył M. Gliszczyński. Życiorysem uzupełnił W. Spasowicz, Petersburg 1857, t. 1, s. 154-156. Ś. Orzelski, Bezkrólewia..., s. 19; idem, Interregni..., s. 250.

4 Ś. Orzelski, Bezkrólewia..., t. 2, ks. 4, s. 14-21; idem, Interregni..., s. 247-250; W. Zakrzewski, op. cit., s. $143-156$.

5 P. Rybak, Zjazd szlachty w Stężycy (maj-czerwiec 1575 r.). Na tle drugiego bezkrólewia, Toruń 2002, s. 83-128; E. Dubas-Urwanowicz, Koronne zjazdy szlacheckie w dwóch pierwszych bezkrólewiach po śmierci Zygmunta Augusta, Białystok 1998, s. 183-198.

6 J. Dzięgielewski, Sejmy elekcyjne. Elektorzy. Elekcje 1573-1674, Pułtusk 2003, s. 54-55; E. Dubas-Urwanowicz, Koronne zjazdy..., s. 248-257.

7 E. Dubas-Urwanowicz, Koronne zjazdy..., s. 63-68.

8 Ibidem, s. 68-73. 
stanowić warunek uznawania jego władzy, wstrzymujący do tego czasu rozpoczęcie formalnej procedury wyboru nowego władcy ${ }^{9}$. Ta jednak powikłana prawno-ustrojowa sytuacja odbijała się wyraźnie na bieżącym funkcjonowaniu Rzeczypospolitej. Kryzys polityczny przełożył się bowiem na kryzys działania instytucji państwa.

Szczególnie dotkliwym problemem ówczesnego bezkrólewia stało się funkcjonowanie sądownictwa. Powstanie stanu, w którym wskutek zwykle zejścia władcy zabrakło osobowo, ale tym samym także instytucjonalnie pojmowanej ówcześnie władzy zwierzchniej, powodowało zawieszenie działania sądów wyższych oraz wygaśnięcie władzy sądów niższych (ex morte regis iudicia omnia cessant; mortus rege mortus est vis legum et iustitiae; mortus rege tribunalia et iudicia, quam nominee regis vigorem obtinent, cessant et silent ${ }^{10}$ ). W tym jednak przypadku sprawa organizacji sądownictwa w okresie bezkrólewia powstałego po wyjeździe króla Henryka okazywała się skomplikowana ze względu na wspomniany stan ustrojowo-prawny, w jakim znalazło się państwo. Problem ten absorbował - bo nie mogło być inaczej - społeczeństwo szlacheckie, zaniepokojone częstym naruszaniem porządku publicznego. Ustalenie więc sposobu funkcjonowania sądów w okresie tak szczególnym, jakim było bezkrólewie, stawało się zagadnieniem podstawowym, gwarantującym trwałość i spoistość państwa w sytuacji zaszłego kryzysu spowodowanego brakiem władzy zwierzchniej ${ }^{11}$.

Jeszcze podczas pobytu króla Henryka działania sądów w wielu prowincjach pozostały zawieszone $\mathrm{z}$ powodu odmówienia przez króla konfirmacji praw $^{12}$. Po jego wyjeździe sądy te tym bardziej nie funkcjonowały, dając pole, jak to określano, dla bezkarności i swawoli ${ }^{13}$. Brak istnienia sądów królewskich stwarzał konieczność odwołania się w sytuacji uznania, że powstało jednak bezkrólewie, do organizacji sądów według wzorca ustalonego w poprzednim bezkrólewiu z 1572 r., czyli powołania sądów kapturowych ${ }^{14}$. Takie jednak rozwiązanie, zastosowane w kilkunastu województwach - sandomier-

9 E. Dubas-Urwanowicz, „Warunek warszawski” z września 1574 roku a status prawno-polityczny państwa, „Czasopismo Prawno-Historyczne” 2008, t. 60, z. 1, s. 193-201.

10 Zdania przytoczone przez O. Balzera pochodzą z akt sądowych z okresu bezkrólewia, O. Balzer, Początki sądów kapturowych, "Ateneum. Pismo naukowe i literackie” 1885, t. 2, s. 151; E. Dubas-Urwanowicz, Bezkrólewie - czas integracji czy podziałów, „Przegląd Historyczny” 1994, t. 85, z. 1-2, s. $35-43$.

11 W. Zakrzewski, op. cit., s. 60-67, 127-130, 173.

12 E. Dubas-Urwanowicz, Koronne zjazdy..., s. 64-65.

13 Ś. Orzelski, Bezkrólewia..., t. 2, ks. 4, s. 9; idem, Interregni..., s. 242; P. Rybak, Zjazd szlachty, s. 41-47; D. Makiłła, Procedura recuperandae possessionis w sprawach dóbr publicznych uchwalona na sejmie konwokacyjnym warszawskim (1574) podczas drugiego bezkrólewia (1574-1576) , [w:] Pro memoria. Księga dla uczczenia pamięci Profesor Krystyny Kamińskiej, red. A. Gaca, Torun 2013, s. 375-390 
skim, krakowskim, ruskim, brzeskim i inowrocławskim, poznańskim, kaliskim, wołyńskim ${ }^{15}$, które znalazły się $\mathrm{w}$ takiej przejściowej sytuacji - było również rozwiązaniem nie tylko doraźnym, z czego zdawano sobie sprawę, ale biorąc pod uwagę skuteczność działania sądów kapturowych w poprzednim bezkrólewiu, były one środkiem o wątpliwej skuteczności. W województwach jednak, w których wahano się, czy wyjazd króla oznaczał powstanie stanu bezkrólewia, sądy królewskie nie bacząc na wyjazd króla dalej funkcjonowały, orzekając nadal w imieniu królewskim. Tym samym w województwach tych nie organizowano sądów kapturowych, ponieważ powstanie stanu bezkrólewia nie uważano za oczywiste, natomiast dotychczasowy system sądów działał ${ }^{16} . \mathrm{Z}$ kolei w województwach, w których sądy królewskie działały, a stan bezkrólewia uznano za powstały, sądy dotychczasowe zawieszano, wprowadzając $\mathrm{w}$ ich miejsce sądy kapturowe. Stan ten pokazywał zróżnicowanie organizacyjne sądownictwa, powodujący jego małą skuteczność. Osobnym problemem było stosowanie apelacji od orzeczeń wydanych przez sądy działające w bezkrólewiu. W przypadku sądów kapturowych, ze względu na nadzwyczajny charakter ich działania, nastawionych bowiem przede wszystkim na rozstrzyganie spraw zagrażających porządkowi publicznemu, sądy te pozostawały w większości jako bezapelacyjne. Zakładano bowiem, że ich działanie będzie nie tylko doraźne, ale jednocześnie krótkie, wyznaczone czasem bezkrólewia ${ }^{17}$. Natomiast w odniesieniu do pozostałych sądów, działających nadal jako królewskie, sprawa apelacji była aktualna. Możliwość stosowania środka odwoławczego od wyroków sądów powszechnych prawnie istniała. Należało więc prawo to uwzględniać, chociaż brak było faktycznej odrębnej instancji odwoławczej, która nie istniała także podczas rządów królewskich. Najważniejszą ponadto kwestią, jaka powstawała w związku z funkcjonowaniem sądów w okresie bezkrólewia - a był to problem stały, niezależnie od sposobu organizacji podczas ówczesnego bezkrólewia, jako kapturowych, czy też nadal sądów królewskich była kwestia egzekucji wyroków. Rozmiar nieprawości, jakie czyniono podczas bezkrólewia, wskazywał, że sprawcy czynów, w których gwałcono porządek

15 Laudum sejmiku województwa sandomierskiego, Opatów, 12 lipca 1574, Biblioteka Polskiej Akademii Nauk w Krakowie, 8338, k. 1-4 (dalej: BPAN Kraków); Postanowienie, które stało się w Proszowicach dnia 16 iulii ad 1574, [w:] Akta sejmikowe województwa krakowskiego, t. 1. 1572-1620, wyd. Stanisław Kutrzeba, s. 37-42 (dalej: ASK); postanowienia sejmiku średzkiego 26-27 lipca 1574 r. zob. Ś. Orzelski, Bezkrólewia, s. 10-13; idem, Interregni..., s. 244-246; Laudum sejmiku wołyńskiego, Łuck 27 lipca 1574 r., [w:] Archiv jugozapadnoj Rosii, cz. 2, t. 1, s. 18-31; Konfederacja województwa ruskiego po odjeździe króla, Lwów 28 lipca 1574 r., [w:] Archiwum Grodzkie i Ziemskie z czasów Rzeczypospolitej Polskiej, t. 20, Lauda wiszeńskie 1572-1648, opr. A. Prochaska, s. 15-20 (dalej: AGiZ).

16 Laudum sejmiku województwa płockiego, Raciąż 4 sierpnia 1574, BPAN Kraków 8336, k. 25-26; Laudum sejmiku ziemi liwskiej, Liw 10 sierpnia 1574 r., BPAN Kraków 8322, k. 23-24.

17 O. Balzer, Geneza Trybunału Koronnego. Studyum z dziejów sądownictwa polskiego XVI wieku, Warszawa 1886, s. $179-180$. 
publiczny, liczyli na daleko idącą bezkarność. Niejasność tej sytuacji, zwłaszcza wobec deklaracji królewskich o swoim powrocie ${ }^{18}$, wymagała ustosunkowania się do powstałego stanu.

Zorganizowanie sądownictwa zdolnego do działania w każdej sytuacji, także w przypadku braku głowy państwa, będącej zwierzchnikiem sądownictwa, zbiegło się jednocześnie z próbą realizacji programu zasadniczej reformy sądownictwa powszechnego, którą zamierzano przeprowadzić począwszy od czasów jagiellońskich ${ }^{19}$. Stronnictwo szlacheckie zmierzające do reformy sądownictwa powszechnego, traktując ją za część programu naprawy Rzeczypospolitej, postrzegało okres bezkrólewia za dogodny moment do jej przeprowadzenia. W programie tym zakładano powstanie sądów powszechnych, które obsadzone miały być wyłącznie przez deputatów szlacheckich, wybranych na sejmikach powiatowych oraz przejęciu przez szlachtę pod względem rzeczowym całego sądownictwa królewskiego łącznie z apelacją. Program ten został wyraźnie rozbudowany $\mathrm{w}$ swoich intencjach $\mathrm{w}$ stosunku do pomysłów dawniejszych, na co wpływ miały niewątpliwie wydarzenia okresu bezkrólewia, sprzyjające emancypacji politycznej szlachty oraz jej dążeń do szczególnego udziału w życiu politycznym. Zakładał więc nie tylko podkreślenie postulatu powstania szlacheckich sądów apelacyjnych, ale przewidywał ponadto $\mathrm{w}$ projektowanym systemie sądownictwa powszechnego wykluczenie udziału w nim możnowładców (dygnitarzy) państwowych, jak również poddanie jurysdykcji szlacheckiej osób duchownych oraz miasta królewskie, a także podporządkowaniu temu sądownictwu Prus Królewskich, przejawiających wyraźne tendencje separatystyczne, nie tylko zresztą $\mathrm{w}$ tym zakresie ${ }^{20}$.

Projekt reorganizacji sądownictwa podniesiony został w czasie elekcji króla Henryka. Wobec jednak trudnej i skomplikowanej sytuacji, w jakiej przeprowadzano elekcję w 1573 r., podczas której planowano początkowo zrealizowanie szerszego programu reform ${ }^{21}$, działania te zostały ograniczone do wydania aktu konstytucyjnego zawierającego podstawowe normy ustrojowe Rzeczypospolitej obejmujące prawa i wolności oraz ich gwarancje ustrojowe, w którym sprawy sądowe pomieszczone zostały w punkcie 14 Artykułów, nazwanych później henrykowskimi22 ${ }^{2}$. Punkt ten, zawierający ograniczone rozwiąza-

18 Ś. Orzelski, Bezkrólewia..., t. 2, ks. 4, s. 6-7; idem, Interregni..., s. 240-241.

19 O. Balzer, Geneza Trybunału..., s. 110-183.

20 W. Szczuczko, Sejmy koronne 1562-1564 a ruch egzekucyjny w Prusach Królewskich, Toruń 1994; Z. Naworski, Szlachecki wymiar sprawiedliwości w Prusach Królewskich (1454-1772). Organizacja i funkcjonowanie, Toruń 2004, s. 46-61; O. Balzer, Geneza Trybunału..., s. 206, 216-218. D. Makiłła, Artykuły henrykowskie (1573-1578). Geneza - Obowiązywanie - Stosowanie. Studium historyczno-prawne, Warszawa 2012, s. 29-49; S. Płaza, Próby reform ustrojowych w czasie Pierwszego Bezkrólewia (1572-1574), Kraków 1969, s. 79-117; E. Dubas-Urwanowicz, Koronne zjazdy..., s. 261-293. 
nia w stosunku do programu reform, przewidywał możliwość stanowienia w każdym województwie własnych sądów, wykonujących również funkcje sądów apelacyjnych, w swej idei podobnych do znanych niektórym województwom, z okresu jeszcze przed elekcją, sądów najwyższej instancji, mających zajmować się sądzeniem przede wszystkim spraw zaległych, aż do ich załatwienia. Możliwość wprowadzenia tych sądów sformułowano jako sui generis uprawnienie przyjęte w postaci zastrzeżenia pozwalającego na ich utworzenie we wszystkich województwach, które do tej pory takich sądów nie miały. Przewidziano jednakowoż, w przypadku wyrażenia takiej woli przez województwa byłyby wyrażały, możliwość oddania tego sądownictwa na powrót w ręce królewskie, czyli jego ponowne scentralizowanie ${ }^{23}$. Rozwiązanie to przyjmowane jako posunięcie tymczasowe, pozwalające na wprowadzenie spraw sądowych do aktu konstytucyjnego, pozwalało jednocześnie stronnictwu dążącemu do reformy sądownictwa na zachowanie otwartej drogi do podniesienia tego problemu w przyszłości. Przede wszystkim pozostawiało możliwość przeprowadzenia dyskusji w sprawie rozstrzygnięcia czy instancja apelacyjna, jaką zakładano, że jednak kiedyś powstanie, będzie zorganizowana centralnie w skali całego państwa, czy też powstawać będzie ona dla każdej z jednostek terytorialnych oddzielnie, co w jakimś sensie przewidziane zostało właśnie w 14 punkcie Artykułów henrykowskich ${ }^{24}$.

Postulat przeprowadzenia reformy sądownictwa w pełnej wersji przedstawiony został ponownie w czasie obrad sejmu koronacyjnego króla Henryka ${ }^{25}$. Także i tym razem wskutek znacznej różnicy zdań, a zwłaszcza protestów duchowieństwa, postrzegającego w projekcie zamach na swoją pozycję, nie został on przyjęty, mimo że opracowywano go w dwóch różnych wersjach przedstawianych $\mathrm{w}$ odstępie kilkunastu dni ${ }^{26}$. Okres więc nowego bezkrólewia powstały po wyjeździe króla Henryka sprzyjał jednak podjęciu kolejnej

Regni Poloniae et Magni Ducatus Lithuaniae Ordines et Status...; E. H. de Noailles, Henri de Valois, Paris 1867, t. 3, s. 441-442. Sprazwiedliwość pospolita sądową kraje Korony Polskiej niektóre sobie zezwolity ujmując ja z osoby królewskiej; czego im pozwalamy i hamować nie mamy z tym dokładem, iż innym, którzy by chcieli siebie postanowić, wolno być im zawżdy, a poprawa ma być wolna za spólnym zezwoleniem. AGAD, Archiwum Zamoyskich, sygn. 3081, s. 11; Przywilej króla Henryka zatwierdzony 10 września 1573 r., Biblioteka Muzeum Narodowego im. Czartoryskich w Krakowie, Dypl. 966 (dalej: BCzart.); Statuta sub interregno sancita per Serenissimum Dominum Regem Nostrum Electum confirmantur, AGAD Metryka Koronna, 112, k. 14a; Confirmatio Serenissimi Electi Regis Poloniae articulorum ad stabiliendum et augendum Reipublicae statum pertinentium, [w:] Diariusz poselstwa polskiego do Francji, s. 180; Volumina Constitutionum, T. 2, Vol. 1. 1550-1585. Do druku przygotowali S. Grodziski, W. Uruszczak, I. Dwornicka, Warszawa 2005, s. 328; Przywilej króla Henryka, W. Broël-Plater, Zbiór pamiętników do dziejów polskich, t. 3, Warszawa 1859, s. 213.

D. Makiłla, Artykuly henrykowskie..., s. 310-312

O. Balzer, Geneza Trybunatu..., s. 225-227.

25 Ibidem, s. 207-2014.

263 marca pierwszy raz, a następnie 11 i 12 marca 1574 r. Ibidem, s. 229-233. 
próby postawienia problemu sądownictwa. Sejmiki przedkonwokacyjne, które obradowały już w lipcu 1574 r. w związku z mającym miejsce miesiąc wcześniej nagłym wyjazdem królewskim, nie podjęły problemu reformy sądownictwa w sposób wyraźny i powszechny, skupiając swoją uwagę przede wszystkim na kwestiach bieżących. Nakazywano jednak na nich, aby sądy odbywały się zgodnie z porządkiem przyjętym w poprzednim bezkrólewiu, czyli przy udziale czterech deputatów. Zakazywano ponadto przedawnienia prawa, zaś starostowie mieli odbywać sądy nie w imieniu własnym, czyli królewskim, ale w imieniu Rzeczypospolitej ${ }^{27}$. Pomimo więc nieporuszania problemu reformy sądownictwa, a bardziej skupieniu się na rozstrzyganiu w województwach czy należy już powoływać właściwe dla bezkrólewia sądy kapturowe, czy też poprzestać na sądach królewskich, sprawa ta nie zniknęła jednak z kręgu zainteresowania szlachty. Podniesiona została ponownie w czasie obrad wspomnianej już konwokacji warszawskiej zwołanej na 24 sierpnia 1574 r. przez prymasa Jakuba Uchańskiego, ale rozpoczętej dopiero 30 sierpnia 1574 r. Zjazd ten zorganizowany $\mathrm{w}$ warunkach kryzysu i niepewności, związanej z wyjazdem królewskim, stał się jednocześnie miejscem, na którym przytoczono wiele przypadków naruszenia prawa i porządku publicznego. Sprawy te, przedłożone uczestnikom zjazdu przez poszkodowanych, miały w większości czysto prywatne podłoże. Niemniej jednak ze względu na ich przedstawienie podczas obrad zjazdu konwokacyjnego, nabierały bardziej powszechnego odniesienia. Skala i rozmiar zakłóceń porządku publicznego były tak znaczne, że za niezbędne uznano konieczność uregulowania tej kwestii, tym bardziej, że jak wskazywano, sądy się rozprzęgły, co powodowało bezkarność i swawolę ${ }^{28}$. Dla załatwienia tego problemu powołano komisję złożoną z przedstawicieli sejmików i senatorów, której celem miało być przygotowanie stosownego projektu. Na spotkaniu 14 września 1574 r. posłowie lubelscy i sandomierscy złożyli projekt reformy sądownictwa powszechnego ${ }^{29}$, zgodny z uchwałą zjazdu szlachty podjętą na okazywaniu województw sandomierskiego i lubelskiego w Solcu ${ }^{30}$.

27 Ś. Orzelski, Bezkrólewia..., t. 2, ks. 4, s. 10; idem, Interregni..., s. 243; Konfederacya województwa ruskiego po odjeździe króla Henryka, we Lwowie, 28 lipca 1574, AGiZ, t. 20, s. 15-20.

28 S. Orzelski, Bezkrólewia..., t. 2, ks. 4, s. 9; idem, Interregni..., s. 242.

29 Iuditia Ordynaria Generalia Primum in Conventu Electionis Regis subWarschovia deinde in Conventu Coronationis cracoviae correcta ac demum in convocation Generali Warschovensi post discessum serenissimi Henrici regis Glalliarum et Poloniae in Galliam moderata ab omnibus ordinibus Regem aprobata et ratificata, Biblioteka Narodowa, III, rkps 4538, k. 342-349; Juditia ordinaria generalia, primum in conventu electionis novi Regis sub Varsavia, in conventu coronationis Cracoviae correcta, ac demum in convocatione generalis Varsaviae post discessum Henrici in Galiam moderata, ab Ordinibus approbata, 1575, BCzart., 84, nr 95, k. 443-465; O. Balzer, Geneza Trybunału..., s. 235-239.

30 W. Śladkowski, Sąd "ultima instantiae" trzech województw: sandomierskiego, lubelskiego i podlaskiego 1574-1577, „Rocznik Lubelski” 1960, t. 3, s. 39. 
W ocenie Oswalda Balzera, który rozważał kwestie prób reformy sądownictwa w tym okresie, propozycja złożona podczas obrad sejmu konwokacyjnego była $\mathrm{w}$ zasadzie powtórzeniem pomysłów znanych z poprzednich okoliczności, kiedy próbowano je zrealizować, podczas sejmu elekcyjnego, a zwłaszcza sejmu koronacyjnego króla Henryka w 1574 r., które tutaj w sprzyjającej sytuacji ponownego bezkrólewia pewne kręgi szlacheckie próbowały wykorzystać dla zrealizowania swoich zamiarów. Pogląd swój Balzer oparł na porównaniu projektów reformy sądownictwa pochodzących z czasu obrad sejmu koronacyjnego oraz konwokacyjnego. W projekcie pochodzącym z 14 września 1574 r. postrzegał jedynie niewielkie zmiany stylistyczne. Zasadniczo projekt ten potwierdzać miał generalną koncepcję szlachty dotyczącą oparcia organizacji sądownictwa powszechnego. Balzer przyjął ponadto, że projekt upadł z powodu oporu przede wszystkim ze strony duchowieństwa, protestującego przeciwko objęciu osób duchownych jurysdykcją świeckich sądów powszechnych. Wskutek różnicy zdań, jaka pojawiła się podczas obrad konwokacji, sprawę przekazano komisji powołanej spośród szlachty oraz dygnitarzy zarówno świeckich, jak i duchownych. W związku z tym, że nie osiągnięto porozumienia projekt przekazano sejmikom, na których sprawa ta, jak się powszechnie przyjmuje, przepadła ${ }^{31}$.

Przyczyna jednakże tego stanu rzeczy nie wydaje się jednak zupełnie jednoznaczna. Kwestie sądowe mocno zaabsorbowały sejmiki pokonwokacyjne ${ }^{32}$. Na zwołanych po konwokacji w ciągu listopada i grudnia 1574 r. obradach sejmików pokonwokacyjnych, jakie zwyczajowo odbyły się w całej Rzeczypospolitej, żywo zajęto się problemami sądownictwa. Sprawy jednakże reformy sądownictwa, $w$ takim kształcie, $\mathrm{w}$ jakim ją proponowano, zgodnie z uchwałą szlachty lubelskiej i sandomierskiej, którego projekt przedłożony na konwokacji został z niej przekazany sejmikom do przyjęcia, nie podjęto. Jednocześnie jednak sejmiki odwoływały się w swoich ustaleniach dotyczących sądownictwa na postanowienia aktu konfederacji, przyjętego 18 września

Laudum sejmiku ziemi zakroczymskiej, Za

k. 31-33v; Laudum sejmiku województw poznańskiego i kaliskiego, Środa, 29 października 1574 r., [w:] Akta sejmikowe województw poznańskiego i kaliskiego, T. 1 (1572-1632), Cz. 1. 1572-1616, wyd. W. Dworzaczek, s. 19-24. Zob. Ś. Orzelski, Bezkrólewia..., t. 2, ks. 4, s. 56-60; idem, Interregni..., s. 276-279; Laudum sejmiku ziemi zakroczymskiej, Zakroczym 10 listopada 1574 r., BPAN Kraków, 8353, k. 35-35v; Laudum sejmiku łomżyńskiego, Łomża 10 listopada 1574 r., BPAN Kraków, 8331, k. 9-9v; Artykuły sejmiku liwskiego, Liw 11 listopada 1574 r.; BPAN Kraków, 8322, k. 24-26; Laudum sejmiku różańskiego z 11 listopada 1574, BPAN Kraków, 8337, k. 4-5; Uchwały sejmiku województwa krakowskiego o ustanowieniu sądów ultima instantiae w Proszowicach 15 listopada 1574 r., ASK, t. 1, s. 42-48; Laudum sejmiku płockiego, Raciąż 18 listopada 1574 r., BPAN Kraków, 8336, k. 27-28v; Laudum sejmiku sieradzkiego, Szadek 19 listopada 1574 r., BPAN Kraków, 8342, k. 9-42; Sejmik wiszeński ustanawia sąd generalny wojewódzki, Wisznia 1 grudnia 1574, AGiZ, t. 20, s. $22-28$. 
1574 r. ${ }^{33}$, a więc po złożeniu projektu reformy sądów przez posłów lubelskich 14 września $1574 \mathrm{r}$. Usankcjonowane zostały, powołane jeszcze przed elekcją króla Henryka sądy ostatniej instancji tam, gdzie one istniały oraz wskazywał na możliwość wprowadzenia przez poszczególne województwa własnych sądów, powstałych na mocy punktu 14 Artykułów henrykowskich ${ }^{34}$. Tym samym wprowadzano odgórnie w drodze sankcji nadanej przez Stany Rzeczypospolitej decentralizację sądownictwa, co w sposób wyraźny znajdowało się w sprzeczności z koncepcją scentralizowanego sądownictwa, zawartą w złożonym 14 września $1574 \mathrm{r}$. w projekcie szlacheckim. Wprowadzono więc aktem konfederacji odgórnie partykularyzację sądownictwa ${ }^{35}$. O takim stanie rzeczy zadecydował pragmatyzm szlachty lokalnej, która została zdominowana problemami bieżącego funkcjonowania sądownictwa, co ze względu na ilość gwałtów i brak skutecznych instancji sądowych było sprawą pilniejszą, aniżeli wprowadzanie reformy obliczonej na długie miesiące debaty, jaka musiałaby się odbyć $\mathrm{w}$ tej sprawie $\mathrm{w}$ każdym $\mathrm{z}$ terytoriów. Ponadto, zgoda na takie rozwiązanie musiałaby wprowadzić $w$ sejmikach rezygnację z części ich uprawnien. Przyjmując koncepcję powstania sądów oddzielnych w każdym województwie sejmiki oparły ich organizacje o ustawę z 1563 r. o tworzeniu sądów ostatniej instancji. De facto więc wprowadzono w poszczególnych województwach sądy prowizoryczne.

Sprawę organizacji sądów potraktowano na sejmikach pokonwokacyjnych, jako rozwiązanie przejściowe. $Z$ reformy sądownictwa, którą przewidywało dążące do jej przeprowadzenia stronnictwo szlacheckie, bynajmniej nie rezygnowano, ale przesuwano ją w czasie. Wprawdzie potrzeba chwili powodowała, że sejmiki zgodziły się na powołanie sądów wojewódzkich, traktowano je jednocześnie jako rozwiązanie doraźne, podyktowane potrzebami okresu bezkrólewia. Z wypowiedzi poczynionych na sejmikach wynikało, że szlachta zamierzała powrócić do sprawy w bardziej stosownych okolicznościach. Nie przesądzano wprawdzie, w którym momencie i w jakim kształcie organizacyjnym, ale wzgląd na protesty duchowieństwa przeciwko tym pomysłom ${ }^{36}$, nie stanowił dla szlachty argumentu, aby z reformy sądownictwa zrezygnować. Kwestie te decydowały o słabej tendencji do tworzenia osobnego sądownictwa wo-

33 Konfederacya przez Pany Rady Duchowne y Świeckie y Posty Ziemskie uczyniona w Warszawie na Konwokacyi po odjechaniu Króla Jmci Henryka z Polski do Francyi. BCzart., 83, k. 283-286; E. H. de Noailles, Henri de Valois, t. 3, s. 605-609. którego pierwsza sesja odbyła się 1 grudnia 1574 r. Do kolejnej sesji doszło dopiero 4 marca 1577 r. w Lublinie. Skuteczność działania tego sądu skłoniła województwo podlaskie do rezygnacji z tworzenia własnego sądu i przyłączenia się do sądu sandomiersko-lubelskiego. W. Śladkowski, op. cit., s. $40-43$.

36 W. Zakrzewski, op. cit., s. 179-180. 
jewódzkiego ${ }^{37}$. Podkreślano też często potrzebę powrotu do sprawy reformy sądownictwa po wyborze króla i objęciu przez niego władzy, co, jak przypuszczano, mogło nie być łatwe. Czas pokazał natomiast, że sprawa reformy sądownictwa stała się jedną z pierwszych, jaka została podjęta przez szlachtę zaraz po objęciu rządów przez króla Stefana, doprowadzając do powstania Trybunału Koronnego ${ }^{38}$.

\section{Bibliografia}

\section{Źródła rękopiśmienne}

Archiwum Główne Akt Dawnych w Warszawie, Acta terrestria et castriensia Varsaviensia, t. 87; Metryka Koronna, t. 112; Archiwum Zamoyskich

Biblioteka Muzeum Narodowego im. Czartoryskich w Krakowie, Dypl. 966, t. 83, 84 Biblioteka Narodowa, III, rkps 4538

Biblioteka Polskiej Akademii Nauk w Krakowie, 8322, 8331, 8336, 8338, 8342, 8353

\section{Źródła drukowane}

Akta sejmikowe województwa krakowskiego, t. 1. 1572-1620, wyd. S. Kutrzeba.

Archiwum Grodzkie i Ziemskie z czasów Rzeczypospolitej Polskiej, t. 20, Lauda wiszeńskie 1572-1648, opr. A. Prochaska.

Diariusz poselstwa polskiego do Francji po Henryka Walezego w 1573 roku, opr. A. Przyboś i R. Żelewski, Wrocław 1963.

Postanovlenia provincialnych sejmikom Ugozapadnoi Rosii, Archiv jugozapadnoj Rosii, Cz. 2, t. 1.

Volumina Constitutionum, T. 2, Vol. 1. 1550-1585. Do druku przygotowali S. Grodziski,

W. Uruszczak, I. Dwornicka, Warszawa 2005.

Zbiór pamiętników do dziejów polskich, wyd. Włodzimierz Stanisław hr. De Broël-Plater, t. 3, Warszawa 1858.

\section{Opracowania}

Balzer O., Geneza Trybunału Koronnego. Studyum z dziejów sądownictwa polskiego XVI wieku, Warszawa 1886.

Balzer O., Początki sądów kapturowych, „Ateneum. Pismo naukowe i literackie” 1885, t. 2.

37 Ibidem, s. 181-182.

38 O. Balzer, Geneza Trybunału..., s. 256-316. 
Dubas-Urwanowicz E., „Warunek warszawski” z września 1574 roku a status prawno-polityczny państwa, „Czasopismo Prawno-Historyczne” 2008, t. 60, z. 1, s. 193-201.

Dubas-Urwanowicz E., Bezkrólewie - czas integracji czy podziałów, „Przegląd Historyczny" 1994 , t. 85 , z. 1-2, s. 35-43.

Dubas-Urwanowicz E., Koronne zjazdy szlacheckie w dwóch pierwszych bezkrólewiach po śmierci Zygmunta Augusta, Białystok 1998.

Dzięgielewski J., Sejmy elekcyjne. Elektorzy. Elekcje 1573-1674, Pułtusk 2003.

Heidenstein R., Dzieje Polski od śmierci Zygmunta Augusta do roku 1594. Ksiag XII. Z łacińskiego przetłumaczył M. Gliszczyński. Życiorysem uzupełnił W. Spasowicz, Petersburg 1857, t. 1.

Makiłła D., Procedura recuperandae possessionis w sprawach dóbr publicznych uchwalona na sejmie konwokacyjnym warszawskim (1574) podczas drugiego bezkrólewia (1574-1576), [w:] Pro memoria. Ksiega dla uczczenia pamięci Profesor Krystyny Kamińskiej, red. A. Gaca, Torun 2013.

Makiłła D., Artykuty henrykowskie (1573-1578). Geneza - Obowiazywanie - Stosowanie. Studium historyczno-prawne, Warszawa 2012.

Naworski Z., Szlachecki wymiar sprawiedliwości w Prusach Królewskich (1454-1772). Organizacja i funkcjonowanie, Torun 2004.

Noailles E. H. de, Henri de Valois, t. 3, Paris 1867.

Orzelski Ś., Bezkrólewia ksiąg ośmioro, czyli dzieje Polski od zgonu Zygmunta Augusta r. 1572 aż do r. 1576 skreślone przez Świętosława z Borzejewic Orzelskiego, starostę radziejowskiego. Przełożył z rękopisu Cesarskiej Publicznej Biblioteki, przypisami i życiorysem uzupetnił Włodzimierz Spasowicz, Petersburg 1856, t. 2 , ks. 4 .

Orzelski Ś., Interregni Poloniae libri VIII, wyd. E. Kuntze, Kraków 1917.

Płaza S., Próby reform ustrojowych w czasie Pierwszego Bezkrólewia (1572-1574), Kraków 1969.

Rybak P., Zjazd szlachty w Stężycy (maj-czerwiec 1575 r.). Na tle drugiego bezkrólewia, Toruń 2002.

Serwański M., Henryk Walezy w Polsce, Kraków 1976.

Szczuczko W., Sejmy koronne 1562-1564 a ruch egzekucyjny w Prusach Królewskich, Toruń 1994.

Śladkowski W., Sąd "ultima instantiae” trzech województw: sandomierskiego, lubelskiego i podlaskiego 1574-1577, „Rocznik Lubelski” 1960, t. 3.

Zakrzewski W., Po ucieczce Henryka. Dzieje bezkrólewia 1574-1575, Kraków 1878. 